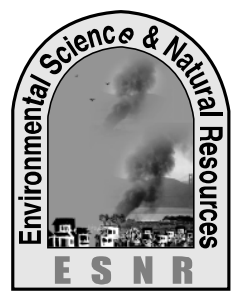

J. Environ. Sci. \& Natural Resources, 7(1): 215 - 226, 2014

ISSN 1999-7361

\title{
Performance of Rhizobia And Nitrogen on Nodulation Yield and N Uptake by Soybean in Saline Soil
}

\author{
M. M. Sultana ${ }^{1}$, M. A. Haque ${ }^{2}$, M. S. A. Reza ${ }^{2 *}$ and M. A. H. Chowdhury ${ }^{3}$ \\ ${ }^{1}$ Vrije University of Brussels, Brussels, Belgium \\ ${ }^{2}$ Department of Food Technology and Nutritional Science \\ Mawlana Bhashani Science and Technology University, Santosh, Tangail-1902, Bangladesh \\ ${ }^{3}$ Department of Agricultural Chemistry \\ Bangladesh Agricultural University, Mymensingh-2202, Bangladesh
}

\begin{abstract}
A pot experiment was conducted in net house to study the effect of different rhizobial strains and $\mathrm{N}$ fertilizer on nodulation, growth, yield, N content and its uptake by soybean cv. Shohag. Saline soil was collected from Fultala of Khulna district. The experiment was laid out in the factorial combination following completely randomized design. There were altogether 16 treatment combinations ( 4 inocula $\times 4$ fertilizer levels) replicated thrice. Four inocula viz., No strain, strain-102, strain-J43 and mixed strains (102 and J43) and four Levels of N viz., $0\left(\mathrm{~N}_{0}\right), 10\left(\mathrm{~N}_{10}\right), 15\left(\mathrm{~N}_{15}\right)$ and $20\left(\mathrm{~N}_{20}\right) \mathrm{kg} \mathrm{N}^{-1}$ were used. Both rhizobial strains and $\mathrm{N}$ alone or in combination significantly affected the nodulation, growth, yield, $\mathrm{N}$ content and its uptake by soybean. The highest values of most of the parameters were recorded from the plant inoculated with strain-J43 except the number of leaves plant $^{-1}$. In case of $\mathrm{N}$ level, maximum values of all parameters were found when $\mathrm{N}$ was applied $15 \mathrm{~kg}^{-1}$ which was identical with $\mathrm{N}_{20}$. The treatment combination of strains-J43 and $\mathrm{N}_{15}$ showed best performance with respect to major parameters studied. The overall results thus suggest that rhizobial strains along with $15 \mathrm{~kg} \mathrm{~N} \mathrm{ha}^{-1}$ can be used for producing higher yield and quality of soybean cv. Shohag in the salt affected soil.
\end{abstract}

Key Words: Nitrogen Uptake, Nodulation, Rhizobia, Saline Soil, Soyabean cv. Shohag

\section{Introduction}

Technology developed in the advanced countries may not be immediately appropriate to the small holder farmers in the developing countries. Rhizobial inoculation of legumes is one such technology. Use of Rhizobium inoculum in the establishment of legumes has been widely recognized, especially in the areas where indigenous nodulation has been found to be inadequate. Further, it has been reported that the legume crops enrich the fertility of the soil Rhizobial inoculation to seeds is well studied and exploitation of this beneficial Nitrogen fixing root nodule symbiosis represents a hallmark of successfully applied agricultural microbiology (Bruno et al., 2003). Soybean (Glycine max L. Merril) is an important grain legume and oilseed crop of the world. About 83,695 thousand hectares of land in the world is under cultivation of soybean and annual production is approximately 1.89 .234 thousand metric tons (FAO, 2004). As a grain legume, it is gaining important position in the agriculture of tropical countries including India, Sri Lanka, Thailand and Bangladesh. As a legume crop, soybean can fix atmospheric N symbiotically and about $80-90 \%$ nitrogen demand could be supplied by soybean through symbiosis (Bieranvand et al., 2003). Salinity is a major threat to crop productivity in Bangladesh, where it is developed due to frequent flood by sea water of the Bay of Bengal. Legume-rhizobium symbiosis may play a vital role for overcoming salinity problems. Nitrogen is a major limiting nutrient for plant growth and development. The deficiency of $\mathrm{N}$ is usually supplemented by high cost inorganic $\mathrm{N}$ fertilizers like urea. Unfortunately the use of this vital nutrient exceeds hardly $5-15 \%$ in some cases $30 \%$. To reduce the costly fertilizer input Rhizobium-legume symbiosis could be a best alternative strategy of $\mathrm{N}$ amendment in soil. The symbiotically fixed $\mathrm{N}$ can meet up $30-90 \% \mathrm{~N}$ requirement of the plant (Vessey, 2004). This fixed $\mathrm{N}$ is also act as renewable source of $\mathrm{N}$ if the legume crop is rotated with a non-leguminous one. Evidences (Podder et al., 1999; Rani and Kodandaramaiah, 1997) showed that soybean is quite responsive to the inoculums and the yield of this crop can be increased to a considerable extent using inoculums. With the view in mind, a research work was conducted to achieve the following objectives: (1) to study the effects of different rhizobial strains on nodulation, growth and yield of salt tolerant soybean. (2) To determine the $\mathrm{N}$ content and its uptake by soybean as influenced by different rhizobial strains and nitrogen doses.

\section{Materials and methods}

A pot experiment was carried out in the net house of the Department of Agricultural Chemistry, Bangladesh Agricultural University, Mymensingh during the period from July to November, 2013. Geographically the experimental site is located at 
$24^{\circ} 75^{\prime} \mathrm{N}$ latitude and $90^{\circ} 50^{\prime} \mathrm{E}$ longitude at an elevation of $18 \mathrm{~m}$ above the sea level. The site belongs to the non-calcareous dark grey floodplain soil under the Agro-ecological Zone (AEZ-9) of Old Brahmaputra Floodplains. Soybean cv. Shohag was used as plant material for the experiment. Seeds were collected through the courtesy of Bangladesh Agricultural Research Institute (BARI), Joydebpur, Bangladesh.

\section{Experimental soil and meteorological conditions}

The experimental soil was collected from Fultala of Khulna district. Physical and chemical status of initial soil sample was $8 \%$ sand, $70.60 \%$ Silt, $21.40 \%$ Clay, Silty loam Textural classes, $\mathrm{P}^{\mathrm{H}} 8.0,1.52 \%$ organic carbon, $2.63 \%$ organic matter, $0.18 \%$ total $\mathrm{N}$, available phosphorus $15.02 \mu^{-1}$, exchangeable potassium $0.64 \mathrm{cmol} \mathrm{kg}^{-1}$, exchangeable calcium 3.84 cmol kg ${ }^{-1}$, exchangeable magnesium $0.26 \mathrm{cmol} \mathrm{kg}^{-1}$, available sulphur $97.57 \mu \mathrm{g} \mathrm{g}^{-1}$.

The experimental site was characterized by high temperature, high humidity and heavy rainfall with occasionally gusty winds in April to September (kharif season) and scanty rainfall associated with moderately low temperature during October to March (rabi season). The winter season extends from November to February in Bangladesh. The meteorological data is presented below.

Table 1. Monthly record of temperature, rainfall, relative humidity and sunshine during the study period from July 2013 to November 2013

\begin{tabular}{|c|c|c|c|c|c|c|}
\hline \multirow{2}{*}{ Month } & \multicolumn{2}{|c|}{ Average air temperature $\left({ }^{\circ} \mathbf{C}\right)$} & \multirow{2}{*}{$\begin{array}{c}\text { Total rainfall (mm) } \\
\text { month }^{-1}\end{array}$} & $\begin{array}{c}\text { Relative } \\
\text { humidity }\end{array}$ & $\begin{array}{c}\text { Sunshine (hrs) } \\
\text { month }^{-1}\end{array}$ \\
\cline { 2 - 4 } & Maximum & Minimum & Average & 235.00 & 77.13 & 178.6 \\
\hline July & 31.02 & 21.33 & 26.18 & 212.90 & 74.42 & 175.55 \\
\hline August & 30.07 & 21.07 & 25.57 & 142.50 & 72.25 & 172.07 \\
\hline September & 30.02 & 21.03 & 25.52 & 75.90 & 71.13 & 165.35 \\
\hline October & 26.59 & 20.07 & 23.66 & 0.00 & 78.25 & 168.25 \\
\hline
\end{tabular}

Source: Department of Irrigation and Water Management, Bangladesh Agricultural University, Mymensingh

\section{Experimental treatments}

This was a two-factor experiment. The experimental factors comprised nitrogen fertilization levels of 0 , $10,15,20 \mathrm{~kg} \mathrm{ha}^{-1}$ and rhizobial strain include no strain, strain-102, strain-J43 and mixed strain of 102 and J43. The treatment will be further referred to as $\mathrm{N}_{0}, \mathrm{~N}_{10}, \mathrm{~N}_{15}$ and $\mathrm{N}_{20}$ whereas the rhizobial strains are respectively referred to as $S_{0}, S_{1}, S_{2}$ and $S_{3}$. There were 16 treatment combinations $(4$ strains $\times 4$ fertilizer levels) replicated thrice.

\section{Experimental design and layout}

The experiment was laid out in completely randomized design with 3 replications. Treatments were assigned at random to each unit pot for each replication. Forty eight pots were arranged in the net house as per lay out plan. Pots having the diameter of $30 \mathrm{~cm} \times 30 \mathrm{~cm}$ were used and soil in each pot was $8 \mathrm{~kg}$. Soils were collected from $0-15 \mathrm{~cm}$ depth, pulverized, inert materials, dead insect pests and plant residues were removed. The soil was air dried and then mixed thoroughly and placed in the pots at the rate of $8 \mathrm{~kg} \mathrm{pot}^{-1}$. Fertilizers at the recommended dose were added and thoroughly mixed with the soil before putting them in the pots. Urea, triple superphosphate, muriate of potash, gypsum and cow dung was applied according to the fertilizer recommendation guide (BARC, 2005). Half amount of urea and full doses of other fertilizers were applied three days before seed sowing. The rest half amount of urea was applied at 20 days after sowing (DAS). To avoid fungal infection seeds were surface sterilized by soaking the seeds with $1 \%$ sodium hypochlorite for one minute followed by washing 6-8 times in tap water and three times in distilled water. After sterilization, the seeds were soaked in rhizobial culture for two hours then 810 seeds were sown in each pot very carefully to avoid contamination among the rhizobial strains. Seeds were sown in the pots on July, 5, 2013 and covered by soil. Intercultural operations were done to ensure normal growth of the crops. Weeding and thinning were done simultaneously after 15 and 30 DAS. The seedlings of the crop emerged out within 68 DAS. Significant soil moisture content was maintained by daily addition of distilled water. The crop was attacked by pod borer and controlled by applying diazinon 1 liter ha ${ }^{-1}$ on September, 14, 2013. The crop was harvested on the November 5, 2013, after 120 DAS. The total yield for each pot was recorded. The plant samples were tagged and oven dried for 72 hours until moisture content reaches to minimum condition. The dried materials of each treatment was weighed and stored for chemical analyses. 


\section{Parameters studied}

The following parameters were calculated for each treatment.

Physical parameters included Plant height $(\mathrm{cm})$, Nodule number plant ${ }^{-1}$, Number of leaves plant ${ }^{-1}$, Number of branches plant ${ }^{-1}$ Number of pods plant ${ }^{-1}$, Number of seeds plant ${ }^{-1}$. Chemical and biochemical parameters included Nitrogen, Protein content.

\section{Plant analysis}

Total $\mathrm{N}$ content of the plant samples was determined by semi-micro kjeldahl method (Page et al., 1982). The amount of $\mathrm{N}$ was calculated using the following formula:

$\% N=\frac{(\mathrm{T}-\mathrm{B}) \times \mathrm{N} \times 1.4 \times 100}{\mathrm{~W}}$

Where,

$\mathrm{T}=$ Titre value $(\mathrm{ML})$ for sample, $\mathrm{B}=$ Titre value (ML) for blank, $\mathrm{N}=$ Strength of $\mathrm{H}_{2} \mathrm{SO}_{4}, \mathrm{~W}=$ Weight of sample, $1.4=$ Correction factor

The uptake of $\mathrm{N}$ was calculated by multiplying the concentration of the nutrient in the grain with the grain yield. In order to determine crude protein in seeds a representative seed samples were taken from each treatment to determine total nitrogen in the seed through Microkjeldahl Method (Page et al., 1982). Then the percentage of protein in seeds was calculated by multiplying the factor 6.25 (Morrison, 1956).

\section{Statistical analysis}

The data were analyzed statistically by F-test (Gomez and Gomez, 1984). The mean comparisons of the treatments were evaluated by LSD test. Analysis of variance was done following the Completely Randomized Design (CRD) with the help of computer package MSTAT developed by Russel (1989).

\section{Results and discussion}

Effects of different rhizobial strains and $\mathrm{N}$ on nodulation of soybean cv. Shohag.

Nodules plant ${ }^{-1}$

Different rhizobial strains significantly influenced the number of nodules plant ${ }^{-1}$ in soybean. The highest number of nodules plant ${ }^{-1}$ (27.58) was observed in plants inoculated with strain-J43 which was significantly higher than those of other treatments. Strain-102 and mixed strains (J43 and 102) inoculated plants produced identical number of nodules plant ${ }^{-1}$. On the other hand, the lowest number of nodules plant $^{-1}$ (13.83) was counted from control (Figure 1 and Table 2). Nodulation might be due to the effective symbiosis between legume and rhizobial strains. Thus, the findings of this experiment is in agreement with those of Slattery et al., (2004) who reported that Rhizobium leguminosarum bv viciae is responsible for effective nodulation of faba bean, lentils and field pea. Egamberdiyeva et al., (2004) investigated the effect of inoculation with Bradyrhizobium japonicum S-2492 on soybean nodulation. They observed positive effects on nodule number. Kavathiya and Pandey (2000) found 69 nodules plant ${ }^{-1}$ by inoculating mungbean seed with Rhizobium. Different levels of $\mathrm{N}$ also showed significant variation with respect to number of nodules plant ${ }^{-1}$.The highest and lowest number of nodules plant ${ }^{-1}$ was 25.91 and 17.83 observed with the treatment $\mathrm{N}_{15}$ and control which was identical with $\mathrm{N}_{20}$ (Figure 1 and Table 2). The interaction effect of different rhizobial strains and $\mathrm{N}$ fertilizer on the number of nodules plant ${ }^{-1}$ revealed that the highest and lowest number of nodules plant ${ }^{-1}$ was 30.33 and 5.00 found in the plant inoculated with rhizobial strain-J43×15 kg N ha ${ }^{-1}$ and control treatment respectively (Figure 2 and Table 3 ). Increase in nodules per plant due to application of inoculation in combination with nitrogen fertilizer was reported by Rashid et al., (1999).

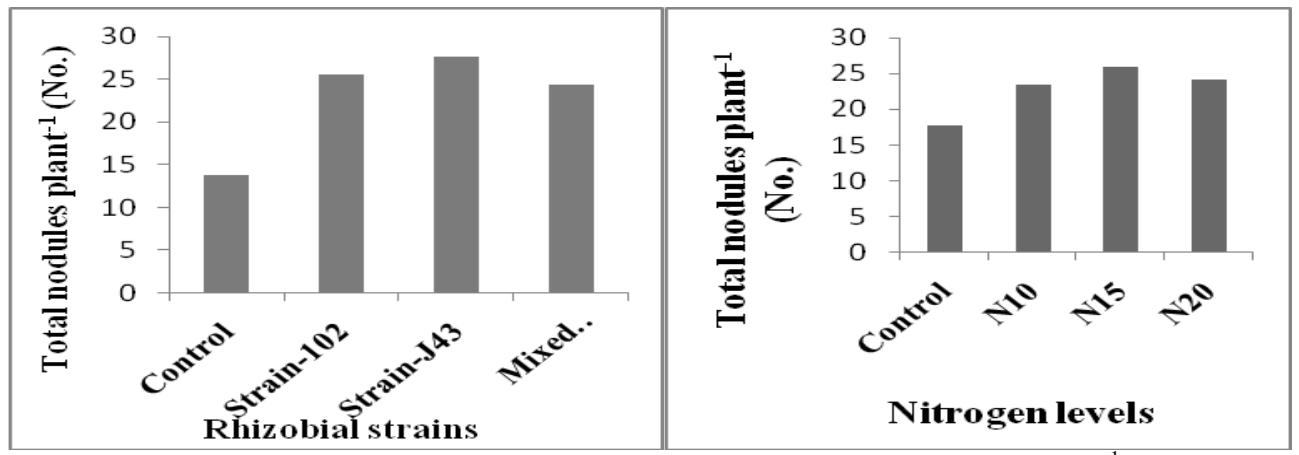

Fig. 1. Effects of different rhizobial strains and different levels of $N$ on number of nodules plant ${ }^{-1}$ of soybean cv. Shohag 


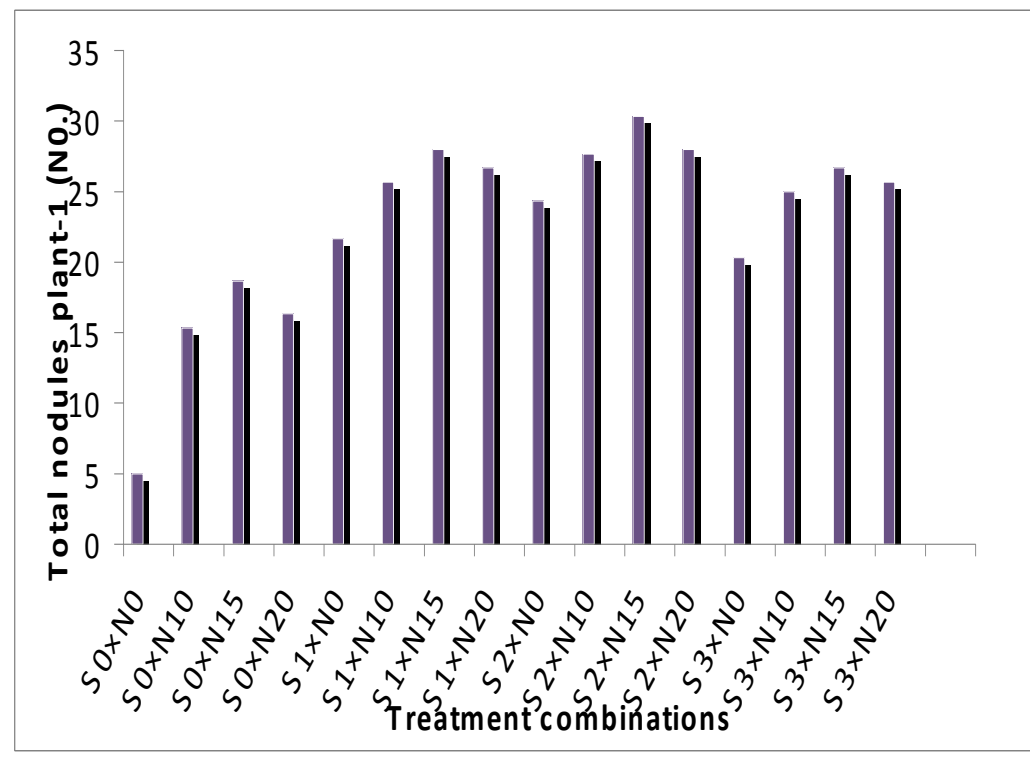

$$
\begin{gathered}
\mathrm{S}_{0}=\text { Control, } \mathrm{S}_{1}=\text { Strain 102, } \mathrm{S}_{2}=\text { Strain J43, } \mathrm{S}_{3}=\text { Mix. }(102 \& \mathrm{~J} 43) \\
\mathrm{N}_{0}=\text { Control, } \mathrm{N}_{10}=10 \mathrm{~kg} \mathrm{ha}^{-1}, \mathrm{~N}_{15}=15 \mathrm{~kg} \mathrm{ha}^{-1}, \mathrm{~N}_{20}=20 \mathrm{~kg} \mathrm{ha}^{-1}
\end{gathered}
$$

Fig. 2. Interaction effects of different rhizobial strains and $\mathrm{N}$ on number of nodules plant ${ }^{-1}$ of soybean cv. Shohag.

\section{Nodule dry weight plant $^{-1}$}

The maximum and minimum nodule dry weight was $0.19 \mathrm{~g}$ and $0.06 \mathrm{~g}$ recorded from the plant inoculated with strain-J43 and non-inoculated plant. In Table 2, it is clear that there was no statistical difference in nodule dry weight of plants inoculated with strain102 and mixed strains (102 and J43). Different rhizobial strains increase the nodulation of the plant compared to control. Icgen (2002) conducted a field experiment with five local and seven standard strains of Rhizobium and the maximum increase in nodule dry weight was found in rhizobial infection compared to control in soybean. Bhuiyan et al., (1998) stated that inoculation with Rhizobium increased nodule dry weight. Table 2 shows that when treated with different $\mathrm{N}$ levels $15 \mathrm{~kg} \mathrm{~N}^{-1}$ showed highest $(0.154 \mathrm{~g})$ and control showed lowest $(0.09 \mathrm{~g})$ nodule dry weight plant $^{-1}$. The results from interaction effect of rhizobial strain and $\mathrm{N}$ fertilizer showed the highest and lowest nodule dry weight was $0.23 \mathrm{~g}$ and $0.01 \mathrm{~g}$ obtained from treatment combination of strain-J43 $\times$ $15 \mathrm{~kg} \mathrm{~N} \mathrm{ha}{ }^{-1}$ and control. The rhizobial strain treatment in conjunction with $\mathrm{N}$ level influenced the nodule dry weight of the plant (Table 3).

\begin{tabular}{|c|c|c|c|c|c|}
\hline Strains & $\begin{array}{l}\text { Fresh nodules } \\
\text { plant }^{-1} \text { (No.) }\end{array}$ & $\begin{array}{c}\text { Dry } \\
\text { nodule wt. } \\
\text { plant }^{-1}(\mathrm{~g})\end{array}$ & $\begin{array}{l}\text { Nitrogen } \\
\text { levels }\end{array}$ & $\begin{array}{l}\text { Fresh nodules } \\
\text { plant }^{-1} \text { (No.) }\end{array}$ & $\begin{array}{c}\text { Dry } \\
\text { nodule wt. } \\
\text { plant }^{-1}(\mathrm{~g})\end{array}$ \\
\hline Uninoculated & 13.833 & 0.069 & $\mathrm{~N}_{0}$ & 17.833 & 0.097 \\
\hline Strain-102 & 25.500 & 0.131 & $\mathrm{~N}_{10}$ & 23.417 & 0.131 \\
\hline Strain J-43 & 27.583 & 0.199 & $\mathrm{~N}_{15}$ & 25.917 & 0.154 \\
\hline Mixed strain & 24.417 & 0.123 & $\mathrm{~N}_{20}$ & 24.167 & 0.141 \\
\hline LSD & 0.247 & 0.004 & LSD & 0.261 & 0.005 \\
\hline
\end{tabular}

Table 2. Effects of different rhizobial strains and different levels of $\mathrm{N}$ on nodule dry weight of soybean cv. Shohag 
Table 3. Interaction effects of different rhizobial strains and N on nodulation of soybean cv. Shohag

\begin{tabular}{|c|c|c|}
\hline Treatment combinations & Total nodule plant ${ }^{-1}$ (No.) & Nodule dry wt. (g) \\
\hline $\mathrm{S}_{0} \mathrm{~N}_{0}$ & 5.000 & 0.016 \\
\hline $\mathrm{S}_{0} \mathrm{~N}_{10}$ & 15.333 & 0.079 \\
\hline $\mathrm{S}_{0} \mathrm{~N}_{15}$ & 18.667 & 0.096 \\
\hline $\mathrm{S}_{0} \mathrm{~N}_{20}$ & 16.333 & 0.084 \\
\hline $\mathrm{S}_{1} \mathrm{~N}_{0}$ & 21.667 & 0.108 \\
\hline $\mathrm{S}_{1} \mathrm{~N}_{10}$ & 25.667 & 0.129 \\
\hline $\mathrm{S}_{1} \mathrm{~N}_{15}$ & 28.000 & 0.147 \\
\hline $\mathrm{S}_{1} \mathrm{~N}_{20}$ & 26.667 & 0.141 \\
\hline $\mathrm{S}_{2} \mathrm{~N}_{0}$ & 24.333 & 0.160 \\
\hline $\mathrm{S}_{2} \mathrm{~N}_{10}$ & 27.667 & 0.193 \\
\hline $\mathrm{S}_{2} \mathrm{~N}_{15}$ & 30.333 & 0.235 \\
\hline $\mathrm{S}_{2} \mathrm{~N}_{20}$ & 28.000 & 0.208 \\
\hline $\mathrm{S}_{3} \mathrm{~N}_{0}$ & 20.333 & 0.103 \\
\hline $\mathrm{S}_{3} \mathrm{~N}_{10}$ & 25.000 & 0.122 \\
\hline $\mathrm{S}_{3} \mathrm{~N}_{15}$ & 26.667 & 0.140 \\
\hline $\mathrm{S}_{3} \mathrm{~N}_{20}$ & 25.667 & 0.129 \\
\hline LSD & 0.065 & 0.001 \\
\hline
\end{tabular}

Effects of different rhizobial strains and $\mathrm{N}$ on growth characters of soybean cv. Shohag

Plant height

The highest and lowest plant height was $86.58 \mathrm{~cm}$ and $73.08 \mathrm{~cm}$ observed in strain-J43 and control (Figure 3). The variation in plant height might be due to the rhizobial inoculation. The above results are in

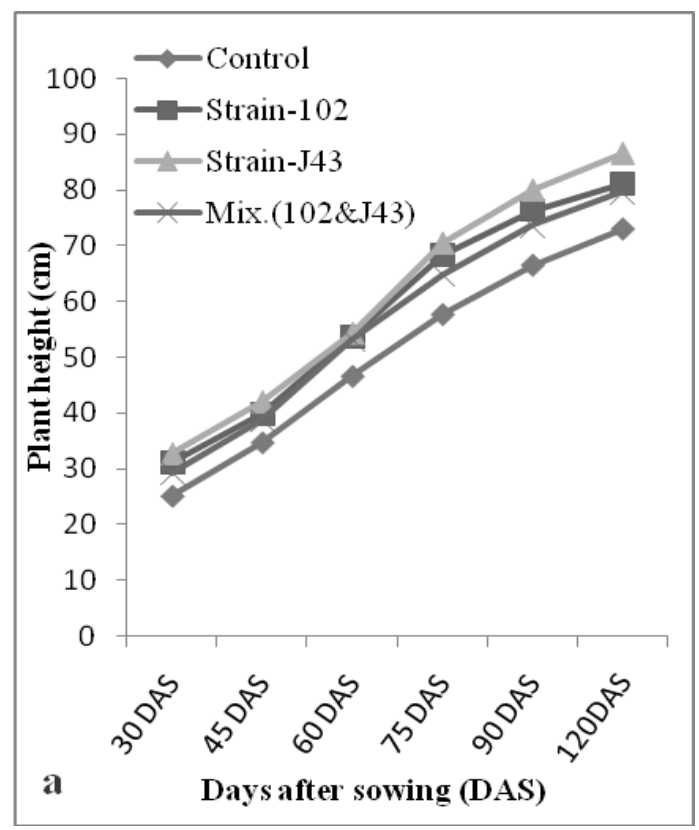

agreement with the findings of Solaiman (1999). When treated with different $\mathrm{N}$ levels the highest $(83.41 \mathrm{~cm})$ and lowest $(76.16 \mathrm{~cm})$ plant height were recorded from $\mathrm{N}_{15}$ and $\mathrm{N}_{0}$ (Figure 3). Different rhizobial strains and $\mathrm{N}$ interaction on plant height was significant as shows in Figure 4.

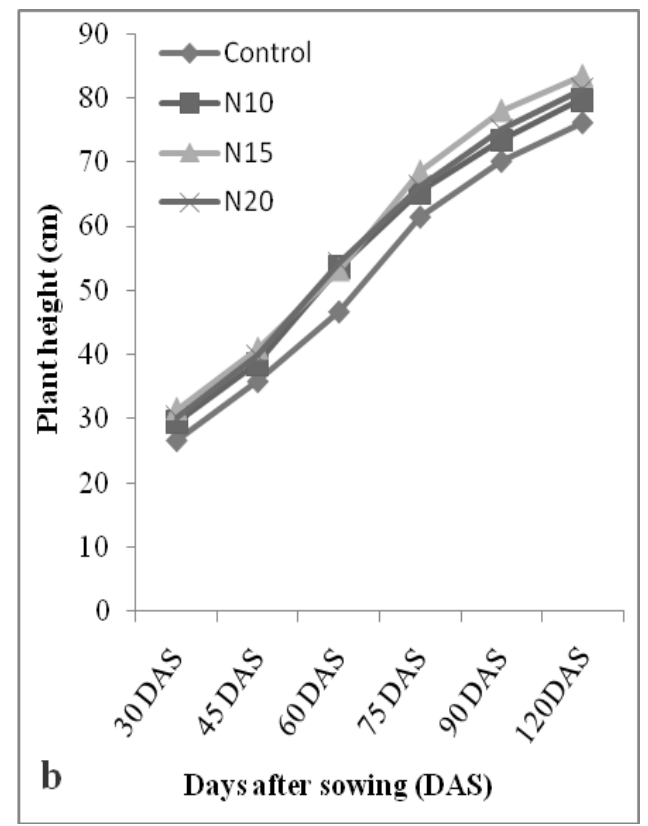

Fig. 3. Effects of different rhizobial strains (a) and different levels of $N$ (b) on plant height at different growth stages of soybean cv. Shohag 


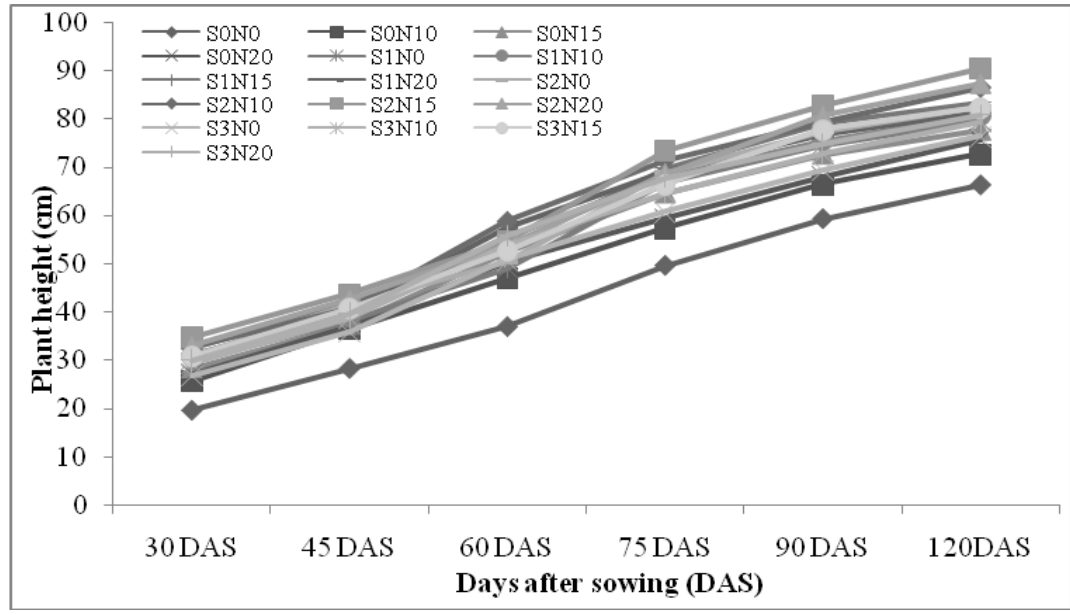

$$
\begin{gathered}
\mathrm{S}_{0}=\text { Control, } \mathrm{S}_{1}=\text { Strain } 102, \mathrm{~S}_{2}=\text { Strain J43, } \mathrm{S}_{3}=\text { Mix. }(102 \& \mathrm{~J} 43) \\
\mathrm{N}_{0}=\text { Control, } \mathrm{N}_{10}=10 \mathrm{~kg} \mathrm{ha}^{-1}, \mathrm{~N}_{15}=15 \mathrm{~kg} \mathrm{ha}^{-1}, \mathrm{~N}_{20}=20 \mathrm{~kg} \mathrm{ha}^{-1}
\end{gathered}
$$

Fig. 4. Interaction effects of different rhizobial strains and $\mathrm{N}$ on plant height at different growth stages of soybean $\mathrm{cv}$. Shohag.

\section{Number of leaves plant ${ }^{-1}$}

Strain-102 produced maximum number of leaves plant $^{-1}(19.08)$ which was identical with strain-J43 where control produced the lowest (15.40) number of leaves (Figure 5). Among the treatments, $15 \mathrm{~kg} \mathrm{~N}$ ha $^{-1}$ and 20 $\mathrm{kg} \mathrm{N} \mathrm{ha}^{-1}$ produced highest number (18.72)

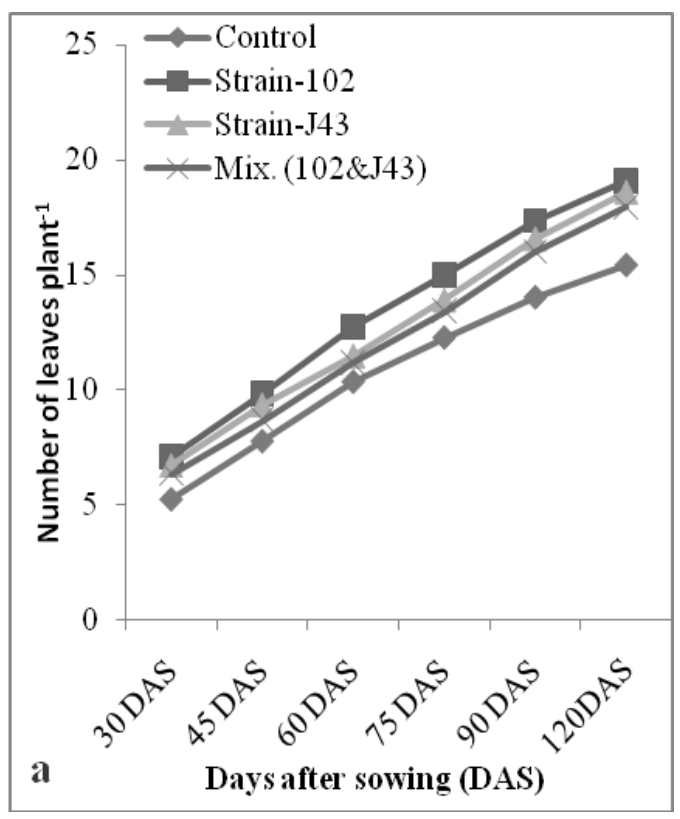

of leaves plant ${ }^{-1}$. Control produced lowest number of leaves plant-1 (16.00) (Figure 5). The interaction effect of rhizobial strain and $\mathrm{N}$ level on number of leaves plant ${ }^{-1}$ showed that strain-102 $\times \mathrm{N}_{15}$ gave the highest (20.33) and control Produced lowest (13.93) number of leaves plant ${ }^{-1}$ (Figure 6).

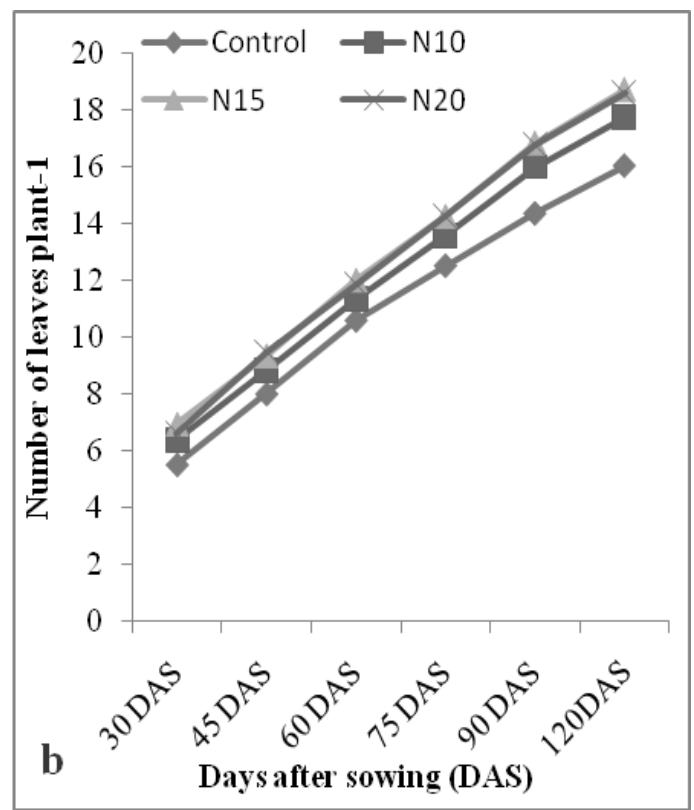

Fig. 5. Effects of different rhizobial strains (a) and different levels of $N$ (b) on number of leaves plant ${ }^{-1}$ at different growth stages of soybean cv. Shohag 


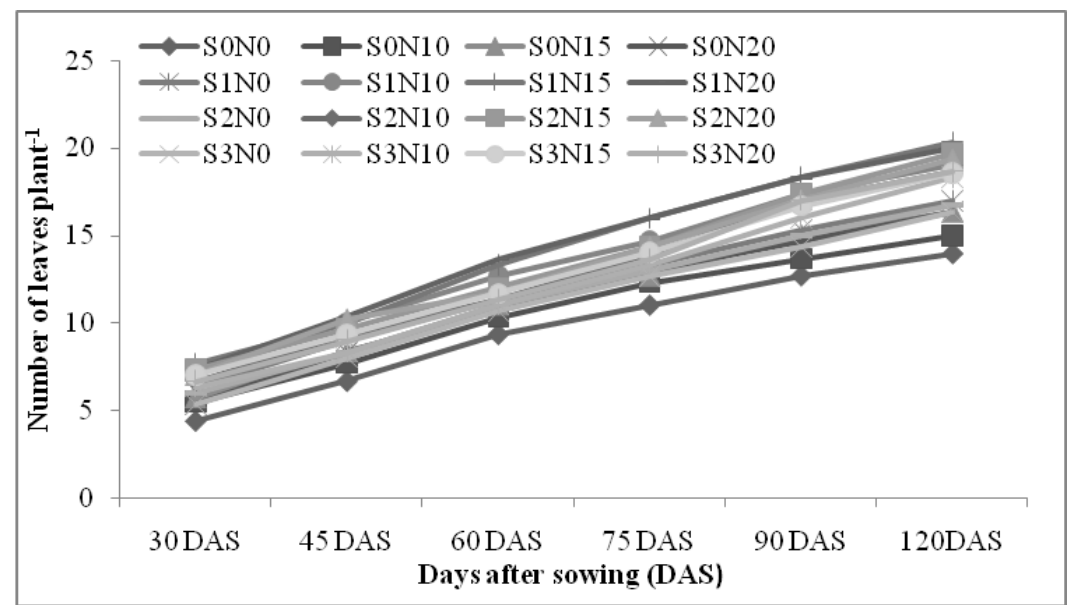

$\mathrm{S}_{0}=$ Control, $\mathrm{S}_{1}=$ Strain 102, $\mathrm{S}_{2}=$ Strain J43, $\mathrm{S}_{3}=$ Mix. (102 \& J43)

$\mathrm{N}_{0}=$ Control, $\mathrm{N}_{10}=10 \mathrm{~kg} \mathrm{ha}^{-1}, \mathrm{~N}_{15}=15 \mathrm{~kg} \mathrm{ha}^{-1}, \mathrm{~N}_{20}=20 \mathrm{~kg} \mathrm{ha}^{-1}$

Fig. 6. Interaction effects of different rhizobial strains and $\mathrm{N}$ on number of leaves plant ${ }^{-1}$ at different growth stages of sobyean cv. Shohag.

\section{Number of branches plant ${ }^{-1}$}

In case of branches plant ${ }^{-1}$ Strain-J43 gave highest (12.09) and control produced the lowest (9.00) number of branch plant (Figure 7). Thakur and Panwar (1995) obtained similar findings from their experiment. Among the treatments $\mathrm{N}_{15}$ produced highest and $\mathrm{N}_{0}$ and $\mathrm{N}_{1}$ produced the lowest number of

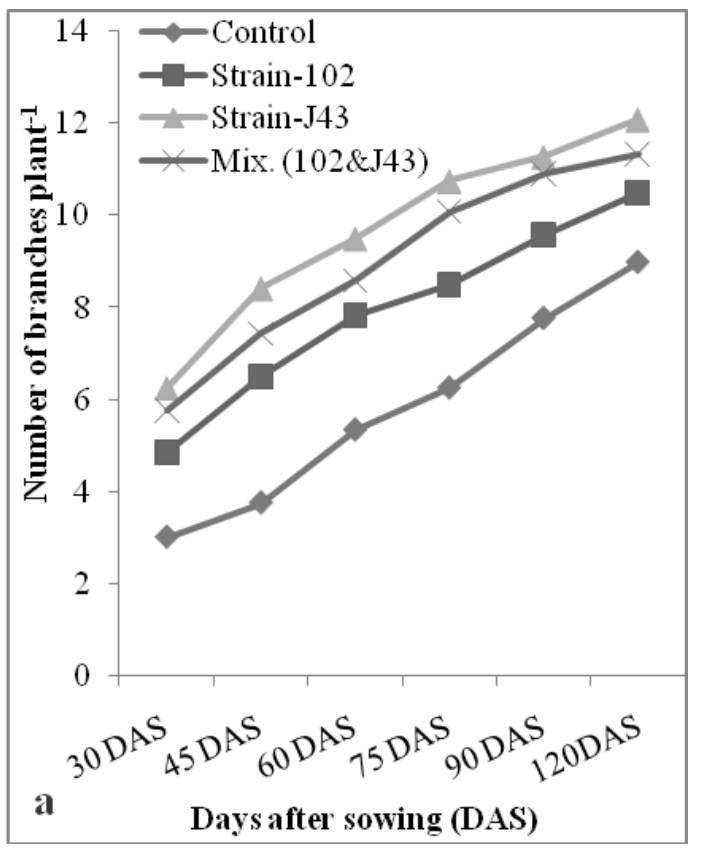

branch plant ${ }^{-1}$ (Figure 7). Increase in branches per plant with increasing doses of $\mathrm{N}$ was observed by Christmas (2002). The interaction effect of different rhizobial strain and $\mathrm{N}$ level showed that strain-J43 $\times$ $\mathrm{N}_{15}$ and Strain-J43 $\times \mathrm{N}_{20}$ produced 12.66 and 12.36 number of branches plant and lowest (8.66) branches plant ${ }^{-1}$ produced from both control and $\mathrm{S}_{0} \times$ $\mathrm{N}_{10}$ treatment (Figure 8).

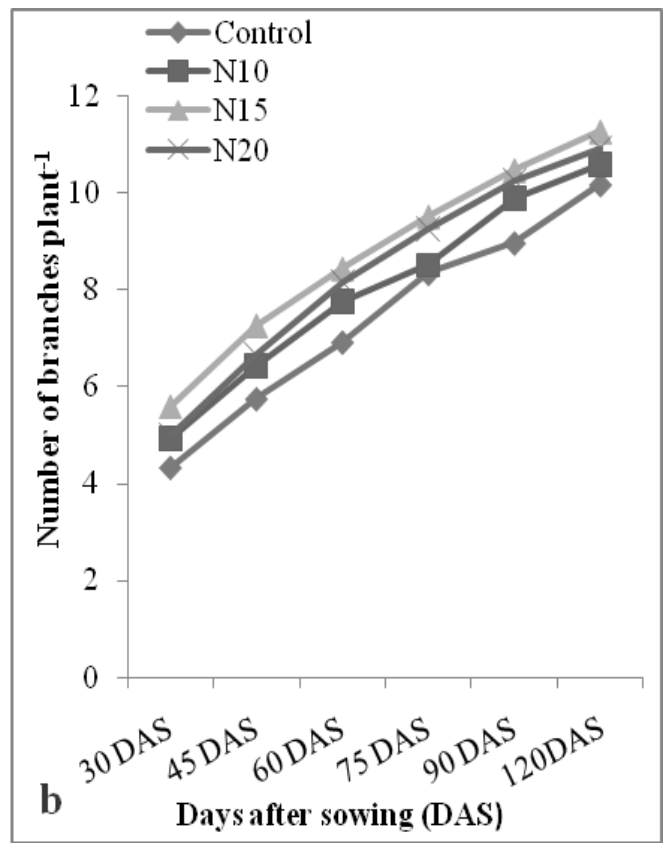

Fig. 7. Effects of different rhizobial strains (a) and different levels of $N(b)$ on number of branches plant ${ }^{-1}$ at different growth stages of soybean cv. Shohag 


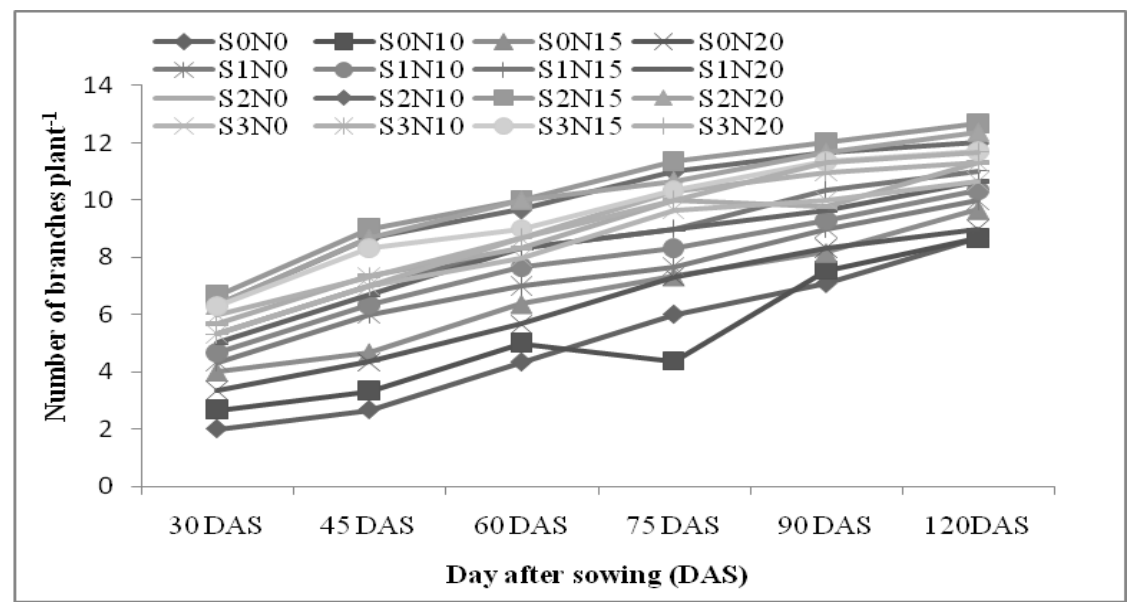

$\mathrm{S}_{0}=$ Control, $\mathrm{S}_{1}=$ Strain 102, $\mathrm{S}_{2}=$ Strain J43, $\mathrm{S}_{3}=$ Mix. $(102 \& \mathrm{~J} 43)$
$\mathrm{N}_{0}=$ Control, $\mathrm{N}_{10}=10 \mathrm{~kg} \mathrm{ha}^{-1}, \mathrm{~N}_{15}=15 \mathrm{~kg} \mathrm{ha}^{-1}, \mathrm{~N}_{20}=20 \mathrm{~kg} \mathrm{ha}^{-1}$

Fig. 8. Interaction effects of different rhizobial strains and $\mathrm{N}$ on number of branches plant different growth stages of soybean cv. Shohag.

Effects of different rhizobial strains and $\mathrm{N}$ on yield and yield attributes of soybean cv. Shohag.

Number of pods and seeds plant ${ }^{-1}$

Inoculation of different rhizobial strains showed significant difference in number of pod and seeds plant $^{-1}$. The maximum number of pod and seeds plant

was 43.58 and 75.66 obtained from the plant inoculated with strain-J43. The minimum number of pod and seeds plant ${ }^{-1}$ was 22.16 and 42.08 counted from control (Figure 9). Similar results also obtained by Solaiman (1999) in chickpea, Feng et al., (1997) in pea, Hoque and Haq (1994) in lentil. Podder et al. (1999) carried out a field experiment with soybean and found that Bradyrhizobium inoculation had

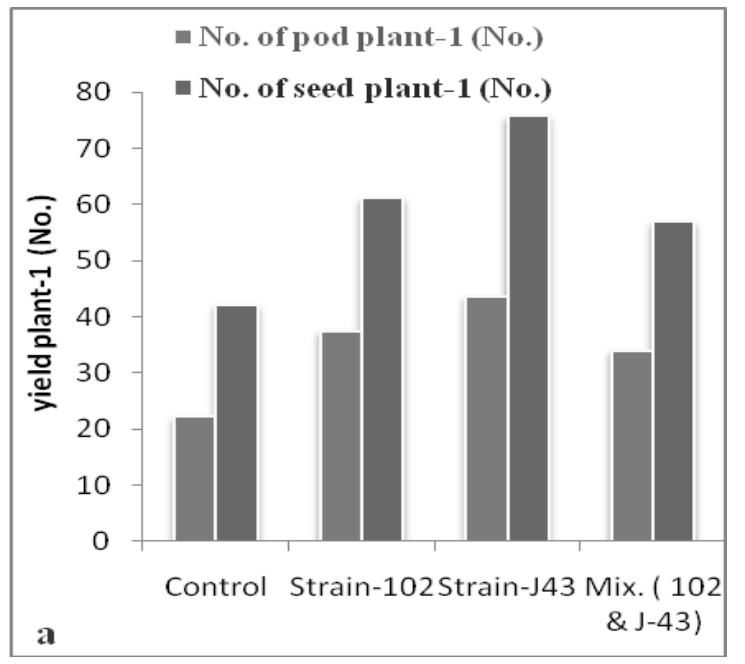

favourable effect on seed number per plant and yield. Number of pods and seeds plant ${ }^{-1}$ was also affected by different levels of $\mathrm{N}$. The maximum (39.08) and minimum (28.83) number of pod plant ${ }^{-1}$ was recorded from the $\mathrm{N}_{15}$ and control, respectively (Figure 9). Almost similar observation was made by Kakar et al., (2002) in pea. The highest number of seeds plant ${ }^{-1}$ (65.83) was found in the treatment $\mathrm{N}_{15}$ and control produced lowest seed plant ${ }^{-1}$ (50.66). The interaction of different rhizobial strains and $\mathrm{N}$ showed that the highest number of pod and seeds was 49.33 and 88.66 obtained from strain-J43 $\times \mathrm{N}_{15}$ and lowest number of pod and seeds were 16.66 and 35.33 found from control (Figure 10).

Fig. 9. Effects of different rhizobial strains (a) and different levels of $\mathrm{N}$ (b) on yield and yield attributes of soybean cv. Shohag 


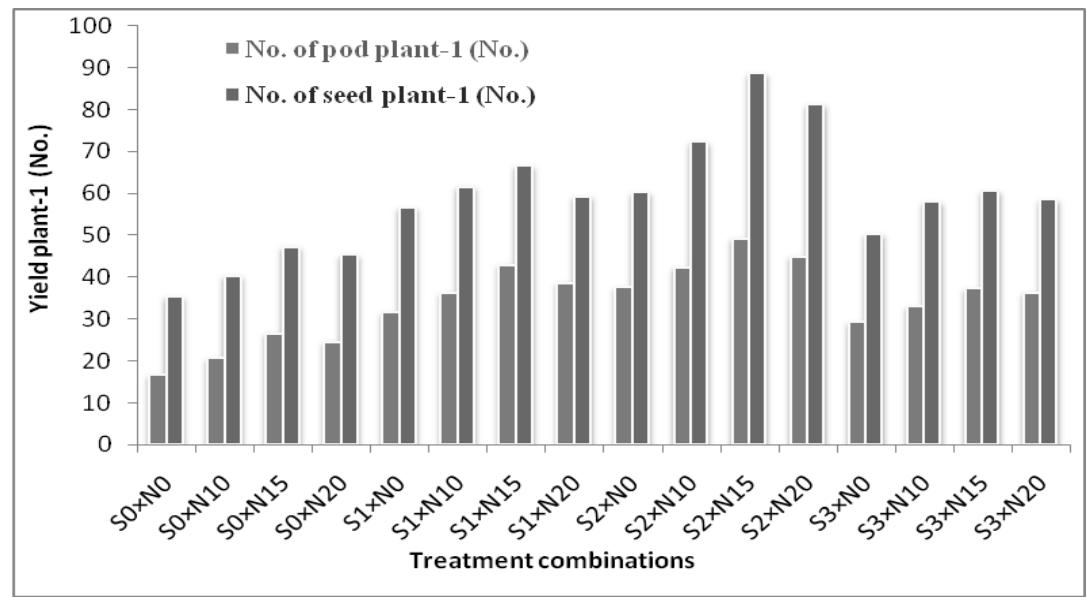

$\mathrm{S}_{0}=$ Control, $\mathrm{S}_{1}=$ Strain 102, $\mathrm{S}_{2}=$ Strain J43, $\mathrm{S}_{3}=$ Mix. $(102 \& \mathrm{~J} 43)$
$\mathrm{N}_{0}=$ Control, $\mathrm{N}_{10}=10 \mathrm{~kg} \mathrm{ha}^{-1}, \mathrm{~N}_{15}=15 \mathrm{~kg} \mathrm{ha}^{-1}, \mathrm{~N}_{20}=20 \mathrm{~kg} \mathrm{ha}^{-1}$

Fig. 10. Interaction effects of different rhizobial strains and $\mathrm{N}$ on yield and yield attributes of soybean $\mathrm{cv}$. Shohag

Effects of different rhizobial strains and $\mathrm{N}$ on protein content of soybean cv. Shohag.

\section{Grain and straw protein content}

Different rhizobial strains inoculation influenced the straw and grain protein content of soybean. The highest grain and straw protein content was $44.06 \%$ and $41.31 \%$ recorded from the plant inoculated with strain-J43. The lowest grain and straw protein content was $39.87 \%$ and $38.25 \%$ recorded from control treated plant respectively (Figure 11). Higher amount of $\mathrm{N}$ increase the $\mathrm{N}$ assimilation and ultimately increase the protein content of the plant. Similar findings was reported by Icgen (2002), he observed that standard strains of Rhizobium increased the protein content of soybean. The maximum increase in

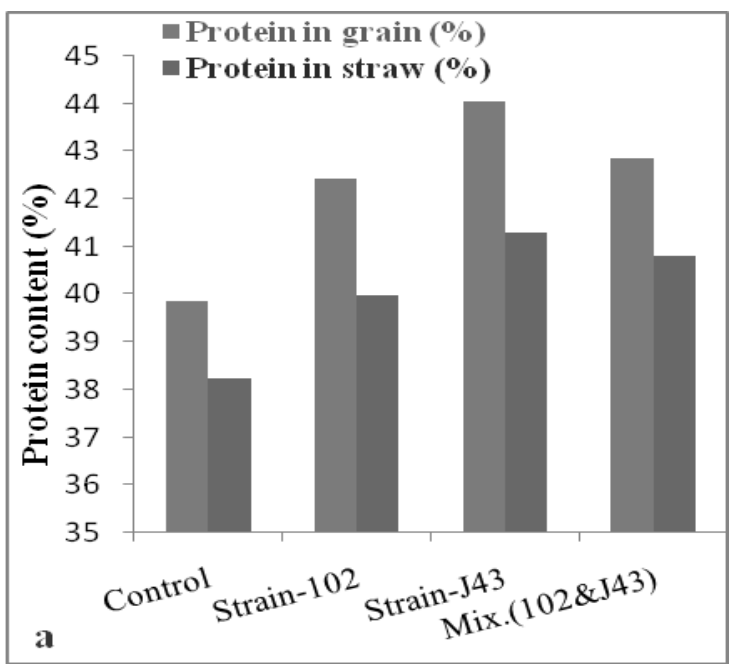

protein content was found in rhizobial inoculation compared to control. Grain and straw protein content varied due to different treatments of nitrogen level. Among the treatments the highest grain and straw protein content was $43.62 \%$ and $40.31 \%$ obtained by the $\mathrm{N}_{15}$ treatment and the lowest was $39.00 \%$ and $38.12 \%$ obtained from control (Figure 11). $\mathrm{N}_{10}$ and $\mathrm{N}_{20}$ treatments were statistically similar. The interacting effect of different rhizobial strains and $\mathrm{N}$ in protein content showed that the highest grain and straw protein content was $46.93 \%$ and $46.50 \%$ found from strain-J43 $\times \mathrm{N}_{15}$ and control recorded lowest grain $(40.56 \%)$ and straw $(39.68 \%)$ protein content (Figure 12).

Fig.11. Effects of different rhizobial strains (a) and different levels of N (b) on protein content of soybean cv. Shohag 


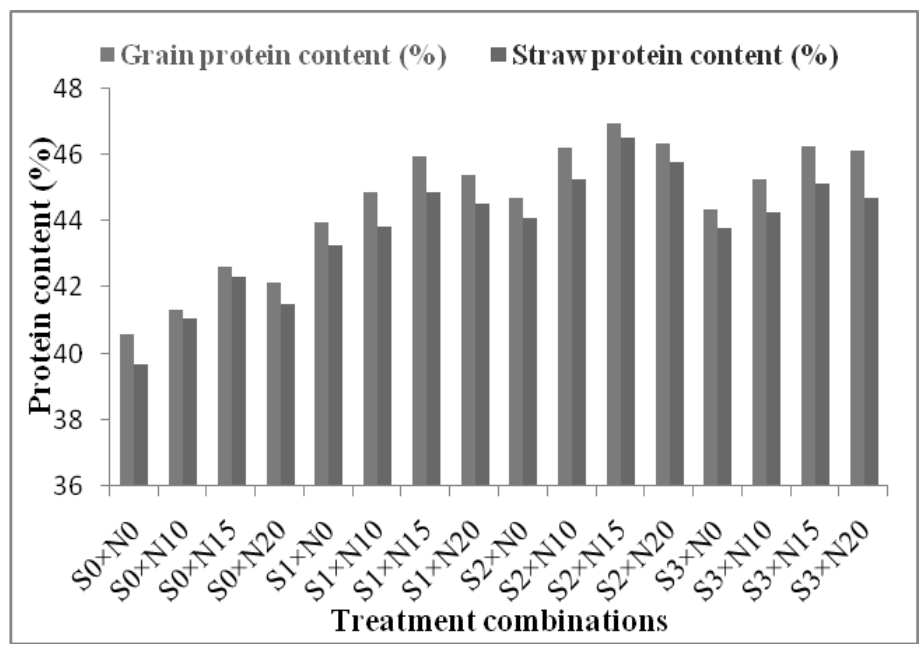

$\mathrm{S}_{0}=$ Control, $\mathrm{S}_{1}=$ Strain 102, $\mathrm{S}_{2}=$ Strain J43, $\mathrm{S}_{3}=$ Mix. $(102 \& \mathrm{~J} 43)$

$\mathrm{N}_{0}=$ Control, $\mathrm{N}_{10}=10 \mathrm{~kg} \mathrm{ha}^{-1}, \mathrm{~N}_{15}=15 \mathrm{~kg} \mathrm{ha}^{-1}, \mathrm{~N}_{20}=20 \mathrm{~kg} \mathrm{ha}^{-1}$

Fig. 12. Interaction effects of different rhizobial strains and $\mathrm{N}$ on protein content of soybean cv. Shohag

Effects of different rhizobial strains and $\mathbf{N}$ on $\mathbf{N}$ content and its uptake by soybean.

\section{Grain $N$ content and $N$ uptake}

When treat with different rhizobial strains the highest grain $\mathrm{N}$ content was $7.05 \%$ and maximum grain $\mathrm{N}$ uptake was $103.48 \mathrm{~kg}$ ha ${ }^{-1}$ obtained from strain-J43 and the lowest grain $\mathrm{N}$ content $(6.38 \%)$ and minimum grain $\mathrm{N}$ uptake was $79.38 \mathrm{~kg}$ ha ${ }^{-1}$ obtained from the control treated plant (Table 4). Seneviratne et al., (2000), and Zhang et al., (2002) reported significant increase in seed and shoot $\mathrm{N}$ of Soybean inoculated with B. japonicum. The findings of this experiment is in agreement with those of Kantar et al., (2003) they reported that bacterial inoculation increased total $\mathrm{N}$ content (\%) significantly compared to control in chickpea. When treated with different $\mathrm{N}$ level the highest $\mathrm{N}$ content, grain $\mathrm{N}$ uptake was $6.98 \%, 99.54$ $\mathrm{kg} \mathrm{ha}^{-1}$ and lowest $\mathrm{N}$ content, grain $\mathrm{N}$ uptake was $6.24 \%, 80.78 \mathrm{~kg}$ ha $^{-1}$ observed from treatment $\mathrm{N}_{15}$ and control group respectively (Table 4).

Table 4. Effects of different rhizobial strains and different levels of $\mathrm{N}$ on $\mathrm{N}$ content and its uptake by soybean cv. Shohag

\begin{tabular}{|c|c|c|c|c|}
\hline & \multicolumn{2}{|c|}{ Grain N } & \multicolumn{2}{|c|}{ Straw N } \\
\hline & Content (\%) & Uptake (Kg ha $\left.{ }^{-1}\right)$ & Content (\%) & Uptake (Kg ha $\left.{ }^{-1}\right)$ \\
\hline \multicolumn{5}{|l|}{ Strains } \\
\hline Control & 6.38 & 79.38 & 6.12 & 97.74 \\
\hline Strain-102 & 6.79 & 94.53 & 6.40 & 139.94 \\
\hline Strain-J43 & 7.05 & 103.48 & 6.61 & 159.12 \\
\hline $\begin{array}{c}\text { Mix. } \\
(102 \text { \& J43) }\end{array}$ & 6.86 & 93.58 & 6.53 & 142.31 \\
\hline LSD & 0.002 & 0.264 & 0.002 & 0.985 \\
\hline \multicolumn{5}{|l|}{ Nitrogen levels } \\
\hline $\mathrm{N}_{0}$ & 6.24 & 80.78 & 6.10 & 117.83 \\
\hline $\mathrm{N}_{10}$ & 6.40 & 86.67 & 6.27 & 129.40 \\
\hline $\mathrm{N}_{15}$ & 6.98 & 99.54 & 6.45 & 147.10 \\
\hline $\mathrm{N}_{20}$ & 6.71 & 93.51 & 6.39 & 133.82 \\
\hline LSD & 0.002 & 0.276 & 0.002 & 0.999 \\
\hline
\end{tabular}

$\mathrm{N}_{0}=$ Control, $\mathrm{N}_{10}=10 \mathrm{~kg} \mathrm{ha}^{-1}, \mathrm{~N}_{15}=15 \mathrm{~kg} \mathrm{ha}^{-1}, \mathrm{~N}_{20}=20 \mathrm{~kg} \mathrm{ha}^{-1}$

\section{Straw $\mathbf{N}$ content and $\mathbf{N}$ uptake}

The highest straw $\mathrm{N}$ content $(6.61 \%)$ and $\mathrm{N}$ uptake (159.12 $\mathrm{kg} \mathrm{ha}^{-1}$ ) was estimated from the plant inoculated with strain-J43. The lowest straw N content $(6.12 \%)$ and $\mathrm{N}$ uptake $\left(97.74 \mathrm{~kg} \mathrm{ha}^{-1}\right)$ was recorded from the non inoculated control plant. Higher straw $\mathrm{N}$ content might be due to the higher $\mathrm{N}$ fixation from the atmosphere by the inoculated 
rhizobial strains. The highest straw $\mathrm{N}$ content $(6.45 \%)$ and straw $\mathrm{N}$ uptake $\left(147.10 \mathrm{~kg} \mathrm{ha}^{-1}\right.$ ) was observed in $\mathrm{N}_{15}$ treatment on the other hand the lowest straw $\mathrm{N}$ content $(6.10 \%)$ and $\mathrm{N}$ uptake $\left(117.83 \mathrm{~kg} \mathrm{ha}^{-1}\right)$ was observed in the control (Table 4).

\section{References}

BARC, 2005. Fertilizer Recommendation Guide. Bangladesh Agricultural Research Council, New Airport Road, Farm gate, Dhaka. P. 8596.

Bhuiyan, M.A.H.; Khanam, D.; Rahman, M.M. and Ali, M.M. 1998. Variation in the symbiotic effectiveness of Bradyrhizobium strains on soybean. Bangla. J. Microbiol., 15: 25-30.

Bieranvand, N. P., Rastin, N. S.; Afarideh, H. and Sagheb, N. 2003. An evaluation of the N fixation capacity of some Bradyrhizobium japonicum strains for soybean cultivars. Iran. J. Agric.Sci. 34 (1): 97-104.

Bruno, J. R., R. Alves, M. Boddey and U. Segundo, 2003. The success of BNF in soybean in Brazil. Plant and Soil. Online. DOI: 10.1023/A: 252(1): 1-9.

Christmas, E. P. 2002. Plant populations and seeding rates for soybeans. AY-217. Purdue University Cooperative Extension Service, West Lafayette, Indiana.

Egamberdiyeva, D.; Qarshieva, D. and Davranov, K. 2004. The Use of Bradyrhizobium to enhance growth and yield of soybean in calcareous soil in Uzbekistan, J. P. I. Growth Reguln., 23: 54-57.

FAO, 2004. FAO year book production. Food and Agriculture Organization of the United Nations, Rome, Italy. P. 57-115.

Feng, Y.; Pan, C.; Wang, D.; Li, Y. and Wei, C. 1997. Isolation of nodule bacteria from Pisum sativum and the application of nitragine from the isolate. J. Trop. Sub Trop. Bot., 5(2):4753.

Gomez, K. A. and Gomez, A. K. 1984. Statistical Procedures for Agricultural Research. $2^{\text {nd }}$ edn, John Wiley and Sons, New York. P. 207-215.

\section{Acknowledgments}

The authors express gratitude to Bangladesh Agricultural University, Mymensingh, Bangladesh for providing all types of technical assistance. Authors thankfully acknowledge the financial assistance from University Grants Commission (UGC), Dhaka, Bangladesh.

Hoque, M.M. and Haq, M.F. 1994. Rhizobial Inoculation and Fertilization of Lentil in Bangladesh. Lens Newsl. 21: 29-30 P.

Icgen, B. 2002. Evaluation of symbiotic effectiveness of various Rhizobium cicer strains. Res. Microbial.,153(6):69-72.

Kakar, A. A.; Saleem, M.; Shah, R. and Shah, S.A.Q. 2002. Growth and marketable green pod yield performance of pea (Pisum sativum L.) under varying levels of NPK fertilizers. Asian J. Plant Sci. 1(5):532-534.

Kantar, F., Elkoca, E., Ogutcu, H. and Angur, O. F. 2003. Chickpea Yields in Relation to Rhizobium Inoculation from Wild Chickpea at High Altitudes. J. Agron. Crop Sci., 189(5):291-297.

Kavathiya, Y. A. and Pandey, R. N. 2000. Interaction studies on Meloidogyne javanica, Rhizobium sp. and Macrophomina phaseolina in mungbean. J. Mycol. Plant Path., 30: 91-93.

Morrison, F. B. 1956. Feeds and feeding. $22^{\text {nd }}$ edn. The Morrison Publishing Company, Ithaca, New York, USA. P. 77.

Page, A.L.; Miller, R.H. and Keeney, D.R. 1982. Methods of Soil Analysis. Part 2, $2^{\text {nd }}$ ed. American Society of Agronomy, Inc. Soil Sci. Soc. Madison, USA. P. 539-622.

Poddar, A. K.; Hossain, M. B.; Chanda, M. C.; Islam, M. Z.; Mondal, N. and Rahman, M. 1999. Selection of effective Bradyrhizobial strains for soybean cultivation for environmental management of Brahmaputra Floodplain

Soil. Bangladesh J. Environ. Sci., 5:56-60.

Rani, B. P. and Kodandaramaiah, D. 1997. Response of soybean (Glycinemax) to Rhizobium inoculation under varying nitrogen levels. Indian J. Agron. 42(1):135-137.

Rashid, A.; Musa, M.; Adal, N.K.; Yaqub. M. and 
Chaudhury, G.A. 1999. Response of groundnut to Bradyrhizobium and a diazotroph bacterial inoculum under different levels of nitrogen. Pakistan J. Soil., 16:89-98.

Russel, D. F. 1989. M-STAT Director. Crop and Soil Science Department, Michigan State University, USA

Seneviratne, G.;Van-Holm, L.H.J. and Ekanayake, E.M.H.G.S. 2000. Agronomic benefits of rhizobial inoculant use over nitrogen fertilizer application in tropical soybean. Field Crop Res. 68:199-203.

Slattery, J.F.; Pearce, D.J. and slattery, W. J. 2004. Effects of resident rhizobial communities and soil types on the effective nodulation of pulse legumes. Soil Biol. Biochem. 36:13391346.

Solaiman, A.R.M. 1999. Nitrogenase activity, yield and yield contributing characters of chickpea as influenced by Rhizobium inoculant in presence and absence of nitrogen. Bangladesh J. Sci. Tech. 1(1):141-144.

Thakur, A.K. and Panwar, J.D.S. 1995. Effect of Rhizobium-VAM interactions on growth and yield in mungbean (Vigna radiata) under field condition. Indian J. Plant Physiol., 38:62-65.

Vessey, J. K. 2004. Benefits of inoculating legume crops with rhizobia in the northern Great Plains. Online. Crop Management doi: 10.1094/CM- 2004-0301-04-RV.

Zhang, H.; Daoust, T.C.; Charles, T.C.; Driscoll, B.T.; Prithiviraj, B. and Smith, D.L. 2002. Bradyrhizobium japonicum mutants allowing improved nodulation and nitrogen fixation of field grown soybean in short season area. $J$. Agric. Sci., 138:293-300. 